\title{
Aleurochiton orientalis Danzig, 1966 (Hemiptera: Aleyrodidae), newly recorded from China, with a key to puparia of all described Aleurochiton species
}

\author{
Ji-Rui Wang, Jon H. Martin, Zhi-Hong Xu*, Yu-Zhou Du**
}

Wang, J. R., Martin, J. H., Xu, Z. H. \& Du, Y. Z. 2016: Aleurochiton orientalis Danzig, 1966 (Hemiptera: Aleyrodidae), newly recorded from China, with a key to puparia of all described Aleurochiton species. — Entomol. Fennica 27: 164 172.

The genus Aleurochiton Tullgren (1907) is here newly recorded from China as $A$. orientalis Danzig (1966). It was collected from Acer mono Maxim (Sapindales: Aceraceae) in Shaanxi Province, but was originally described from the Russian Far East (Southern Primor'ye) by Danzig (1966). The puparial morphology of $A$. orientalis is here illustrated by line art, photomicrographs and scanning electron microscope (SEM) photographs. An identification key to the all five described Aleurochiton species is provided.

J. R. Wang, School of Agricultural \& Food Science, Zhejiang Agriculture \& Forestry University, Linan, 311300, China; and School of Horticulture, Plant Protection \& Institute of Applied Entomology, Yangzhou University, Yangzhou, Jiangsu 225009, China

J. H. Martin, Scientific Associate, The Natural History Museum, London SW7 5BD, U.K.

Z. H. Xu, School of Agricultural \& Food Science, Zhejiang Agriculture \& Forestry University, Linan, 311300, China. *Corresponding author's e-mail: zhhxu@zju.edu.cn

Y. Z. Du, School of Horticulture and Plant Protection \& Institute of Applied Entomology, Yangzhou University, Yangzhou, Jiangsu 225009, China. **Corresponding author's e-mail: yzdu@yzu.edu.cn

Received 2 June 2016, accepted 2 August 2016

\section{Introduction}

The genus Aleurochiton was originally established by Tullgren (1907), with Aleurochiton aceris (Modeer, 1778) as its type species. Currently, the genus contains the following five described species: Aleurochiton acerinus Haupt (1934), Aleurochiton aceris (Modeer, 1778), and Aleurochiton pseudoplatani Visnya (1936) all from Europe only (Danzig 1966, Martin et al.
2000, Martin \& Mound 2007); Aleurochiton forbesii (Ashmead, 1893), known only from the Nearctic Region (North America); and Aleurochiton orientalis Danzig (1966), hitherto only known from the southern Maritime Territory of Russia. Zahradnik (1963) assigned the American species Aleurochiton forbesii to a separate subgenus Nealeurochiton because it differs from the other species in the size of the lingula and vasiform orifice. However, Mound and Halsey 
Fig. 1. Collection localities (China and Russia) of Aleurochiton orientalis Danzig. LPNFP: Liping National Forest Park, NGM: Nangong Mountain.

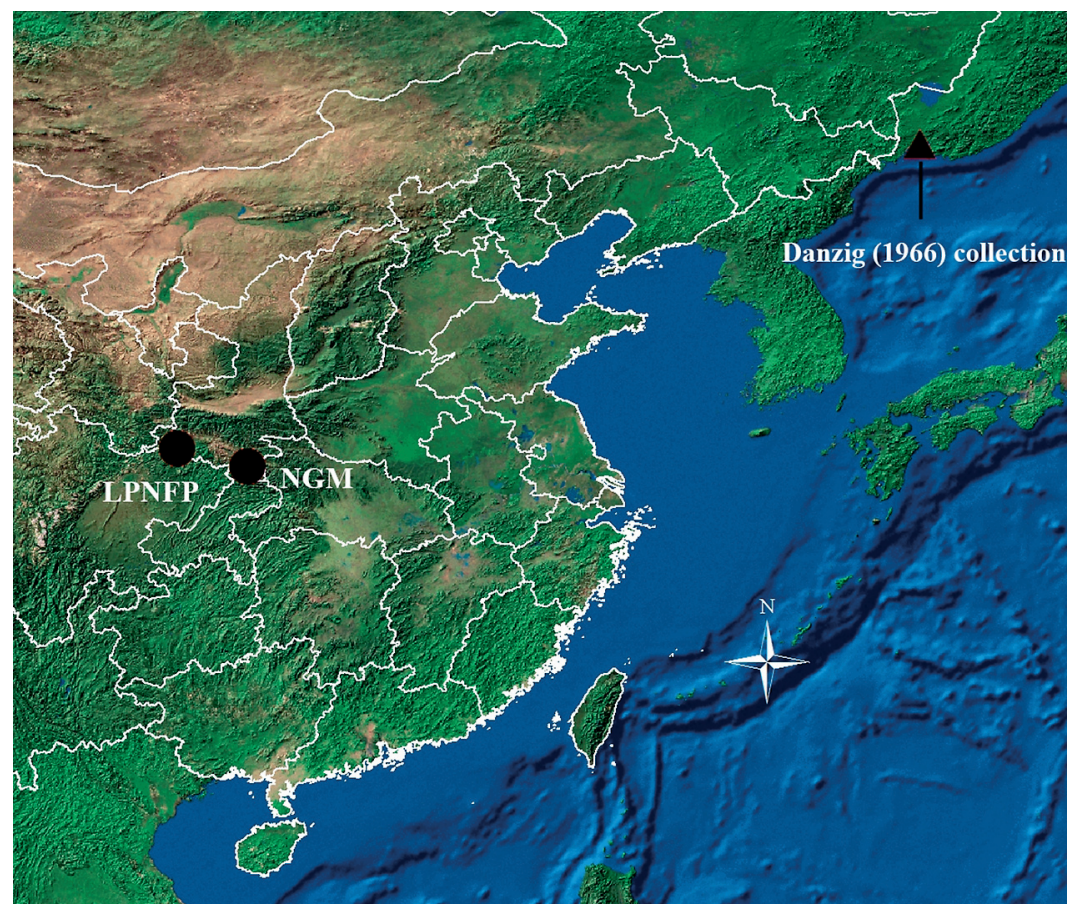

(1978) considered Nealeurochiton to be a junior synonym of Aleurochiton (Martin et al. 2000). Martin and Mound (2007) regarded Nigrinichiton Zahradnik also as a junior synonym of Aleurochiton.

A faunal survey of Aleyrodidae was conducted in two Nature Reserves of Shaanxi Province, China, in July 2012 as the Aleyrodidae fauna in these areas had not been previously investigated in detail. Amongst material collected as part of this survey, we identified the maplefeeding Aleurochiton orientalis Danzig, which is a new species record for China, and also represents the first record of Aleurochiton from China. Here, we provide an up-to-date description of the puparia, and also describe and illustrate the third instar and second instar nymphs, with traditional line drawings, photomicrographs and scanning electron microscope (SEM) photographs.

\section{Materials and methods}

Puparia of A. orientalis were collected from Nangong Mountain and Liping National Forest Park, Shaanxi (Fig. 1), China, in July 2012.

The specimens were mounted following the method given by Martin (1987). The terminology for morphological structures follows BinkMoenen (1983), Martin (1985) and Gill (1990). The measurements and camera lucida drawings were made using an OLYMPUS intelligent microscope BX63 (OLYMPUS Corporation, Tokyo, Japan) located in the Institute of Applied Entomology, Yangzhou University, Yangzhou, China. Two samples were prepared for Scanning Electron Microscope (SEM) studies by cutting the leaf with a puparium still attached, then mounting this on a stub on black carbon conductive adhesive. The SEM images were taken by Philips XL30-Environmental Scanning Electron Microscope (Philips, UK) at $20 \mathrm{kV} / \mathrm{EHT}$ and 80 $\mathrm{Pa}$ between 157 to $1,000 \times$ magnification (Wang et al. 2014).

The specimens are deposited in the Insect Collection of Yangzhou University (YZU), Yangzhou, China and Natural History Museum, London, UK (BMNH).

\section{Aleurochiton}

Aleurochiton Tullgren, 1907, Arkiv für Zoologi, 3: 14. Type species: Chermes aceris ovatus 

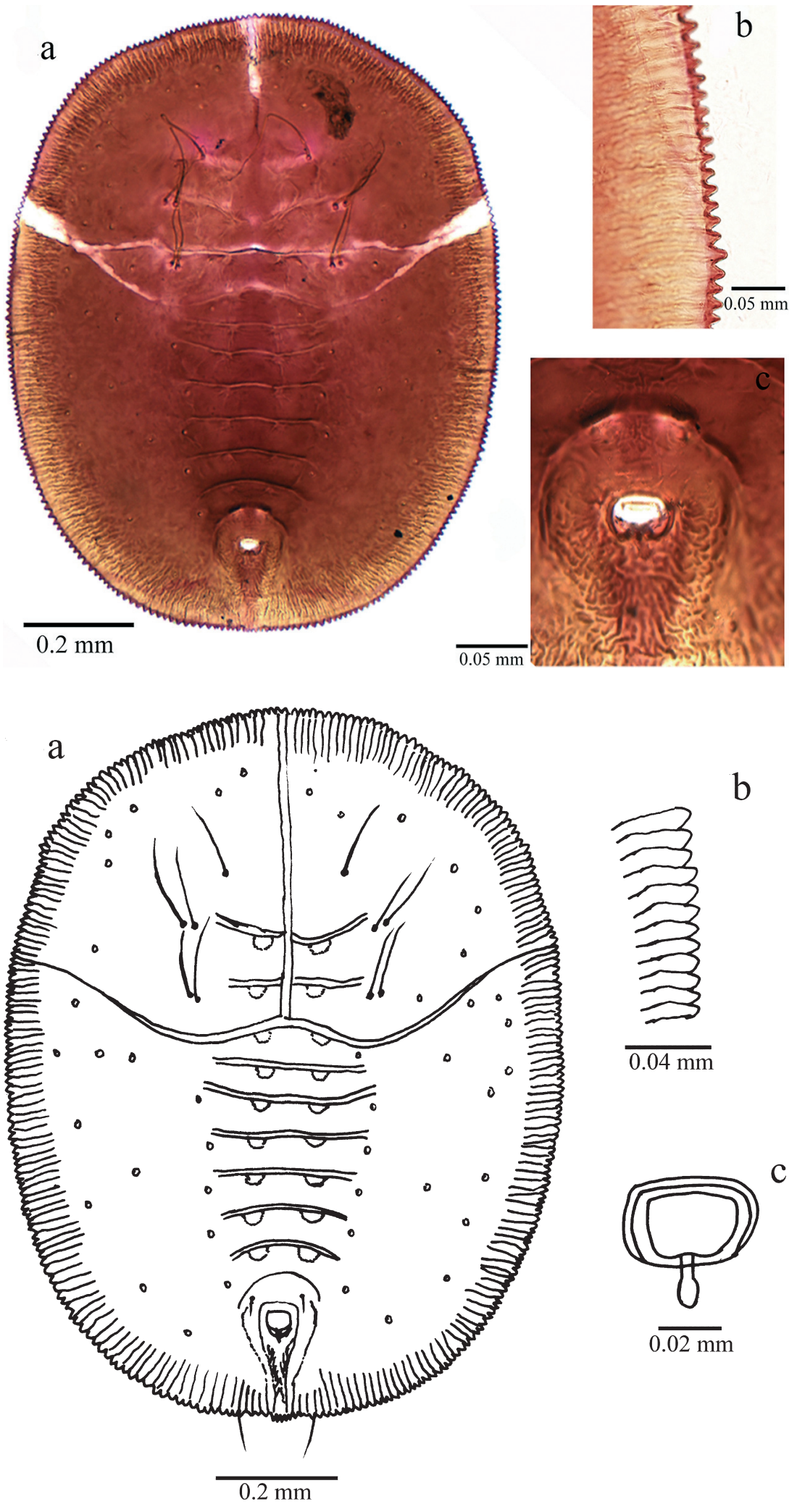

Fig. 2. Aleurochiton orientalis Danzig, slide-mounted specimen. - a. Puparium, dorsal view. $-b$. Margin. - c. Vasiform orifice and caudal furrow.

Fig. 3. Aleurochiton orientalis Danzig. - a. Puparium, dorsal view. - b. Margin. - c. Vasiform orifice. 
Geoffroy, 1762, a rejected trinomial and a synonym of Coccus aceris Modeer, 1778, by monotypy.

Aleurochiton (Nealeurochiton) Sampson, 1943, Entomologica Americana, 23: 201. Type species: Aleurodes forbesii, by monotypy. [Synonymised by Mound \& Halsey, 1978: 27.]

Aleurochiton (Nigrinichiton) Zahradnik, 1987, Vestník Československé Společnosti Zoologické, 51: 70. Type species: Aleurochiton pseudoplatani, by monotypy. [Synonymised by Martin \& Mound, 2007: 9.]

Diagnosis. Puparium medium in size, broadly elliptical in outline, cuticular colour variable, margin crenulate, with waxy secretion on dorsum (especially in overwintering puparia) or along margin. Submarginal area not separated from dorsal disk. Vasiform orifice cordate to rectangular, operculum almost fully occupying vasiform orifice, lingula usually slightly overlapping posterior margin of vasiform orifice; transverse moulting suture reaching margin (Martin et al. 2000).

Puparia of Aleurochiton species somewhat resemble those of some Pealius species in the shape of the puparia and vasiform orifice and other characters, but in most species of Aleurochiton the operculum almost fully occupies the vasiform orifice, the lingula usually slightly overlaps the posterior margin of the vasiform orifice and the transverse moulting suture reaches the puparial margin. However, in species of Pealius the operculum occupies about two-thirds of the vasiform orifice, the lingula is included within the vasiform orifice, and the transverse moulting sutures terminate almost at the margin (Martin et al. 2000). There are also several Pealius species that have the transverse moulting suture extending to the margin as in Aleurochiton.

A characteristic shared by species of Aleurochiton and the European species Pealius quercus (Signoret, 1868) is overwintering as especially robust puparia that fall to the ground on dead leaves and then yield adult whiteflies in the spring. It is probable that some other Pealius species also do this, but the biology of most whiteflies remains unknown. In some Aleurochiton species the overwintering puparia significantly differ from the summer forms of the same species.

Puparia of Aleurochiton species also resemble the species of Apobemisia in the shape of vasiform orifice and other characters, but in species of Apobemisia the operculum occupies about half of the vasiform orifice and the lingula is much longer and larger (Takahashi 1954).

\section{Descriptions of Aleurochiton orientalis}

Aleurochiton orientalis Danzig, 1966 (Figs. 2-4) Aleurochiton orientalis: Danzig, 1966. Entomologicheskoe Obozrenie 45: 365.

Material examined. China, Shaanxi, 4 puparia on 4 slides, on Acer mono Maxim, Nangong Mountain, 18.VII.2012, J. R. Wang, leg., YZU; 4 puparia on 4 slides, on Acer mono Maxim, Liping National Forest Park, 15.VII.2012, J. R. Wang leg., YZU.

Descriptions. Puparia (fourth instar) (Figs. 23). Cinnamon-brown, broadly oval, slightly narrowed in thoracic region, about $1.1 \mathrm{~mm}$ in length, $0.86 \mathrm{~mm}$ in width; with a thin wax band along margin, about $124.5 \mu \mathrm{m}$ long.

Lateral margin: With sclerotized denticles, single row, teeth triangular, about 7-9 denticles in $0.1 \mathrm{~mm}$; anterior and posterior marginal setae absent. Tracheal folds distinct, broad, without special structure. Tracheal combs consisting of 3-4 denticles, smaller than marginal denticles.

Dorsum: Sub-marginal region not clearly separate from dorsal disk, with many transverse striae along sub-marginal area, also with some small pores. Longitudinal and transverse molting suture both extending to margin. A pair of prothorax setae approximately $255 \mu \mathrm{m}$ long and 194 $\mu \mathrm{m}$ apart; a pair of conjugate setae on mesothorax and also on metathorax, approximately $261 \mu \mathrm{m}$ long and $305 \mu \mathrm{m}$ apart. Thorax and abdominal segment sutures well-defined, abdominal segment I $69.4 \mu \mathrm{m}$ long, abdominal segment II-VI $55.6 \mu \mathrm{m}$ long, abdominal segment VII $50 \mu \mathrm{m}$ long. A pair of depressions present at median of each thoracic and abdominal segment sutures. A pair of small pores present on each side of abdominal segments.

Vasiform orifice: Situated in a rugose depression, rectangular, about $42.7 \mu \mathrm{m}$ wide and 28.1 $\mu \mathrm{m}$ long. Operculum rectangular, almost completely covering orifice. Lingula head, about 20 

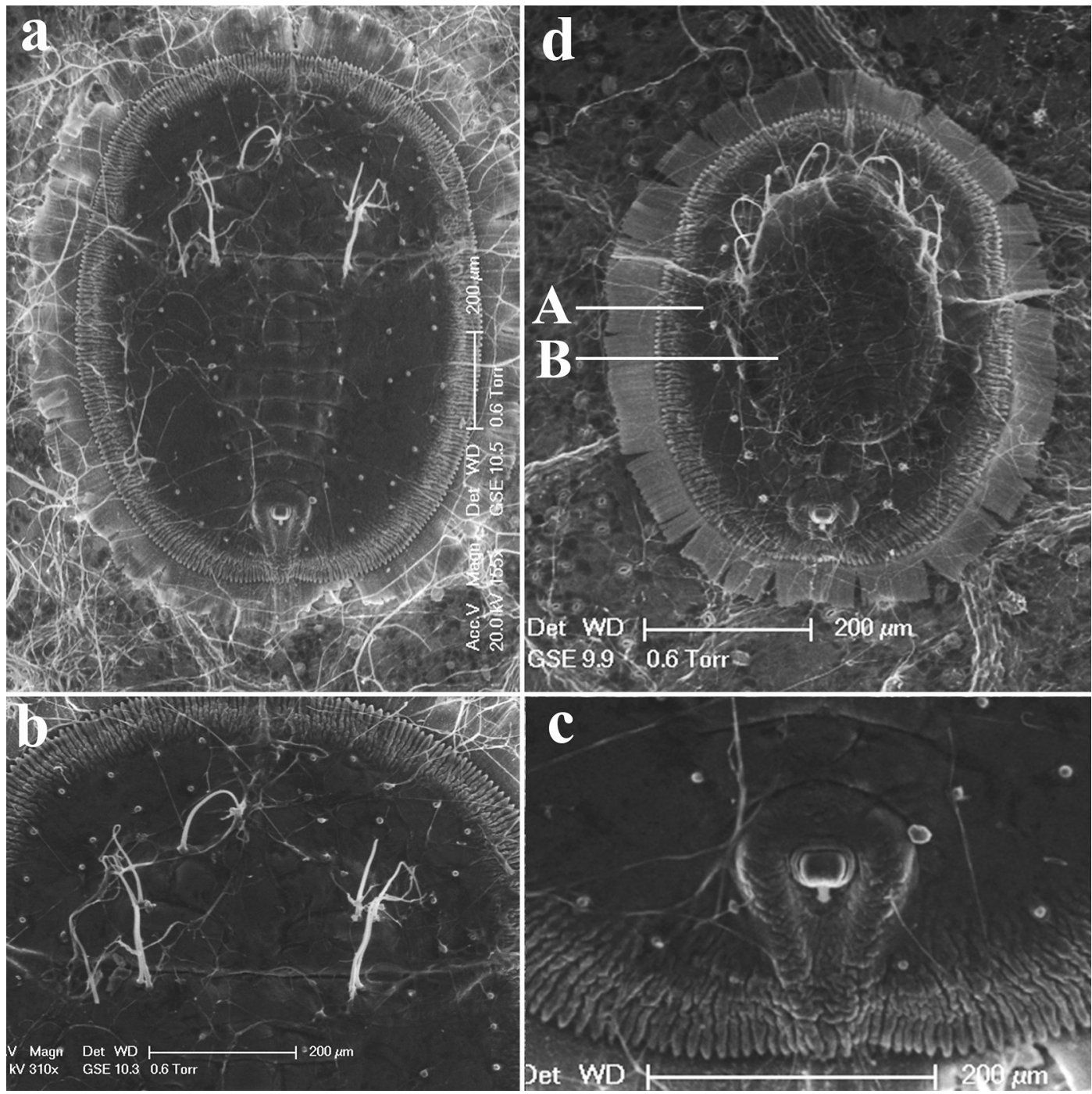

Fig. 4. SEM of Aleurochiton orientalis Danzig. - a. Puparium, dorsal view. - b. Cephalothorax and conjugate setae. - c. Vasiform orifice and caudal furrow. - d. $2^{\text {nd }}$ larval exuvium (B) present on dorsum of $3^{\text {rd }}$ larval instar (A), dorsal view.

$\mu \mathrm{m}$ long, extending beyond orifice. Caudal furrow more strongly sclerotized than surrounding surface. Caudal setae about $137.9 \mu \mathrm{m}$ long.

Third instar (Fig. 4d: A). Shallow brown, elliptical, about $0.59-0.62 \mathrm{~mm}$ long, $0.41-0.43 \mathrm{~mm}$ wide, with wax band along margin, about 59.6 $\mu \mathrm{m}$ long. Other morphological characteristics basically identical with puparia but with only 10 pairs of pores along submarginal.

Second instar (Fig. 4d: B) (based on two specimen, $2^{\text {nd }} / 3^{\text {rd }}$ instar molt). Pale white, elliptical, about $0.34 \mathrm{~mm}$ long, $0.22 \mathrm{~mm}$ wide, with a thin wax band along margin, about $35.4 \mu \mathrm{m}$ long. Marginal, cephalic and thoracic setae not discernible, but caudal setae about $57.1 \mu \mathrm{m}$ long. Submarginal pore absent. Abdominal segment sutures well-defined and sutures extending to margin. Vasiform orifice rectangular, wider than long, operculum rectangular, almost completely covering orifice. Lingula exposed, extending beyond orifice.

First instar and adult. Unknown.

Host plants. Acer mono Maxim (Sapindales: Aceraceae). 


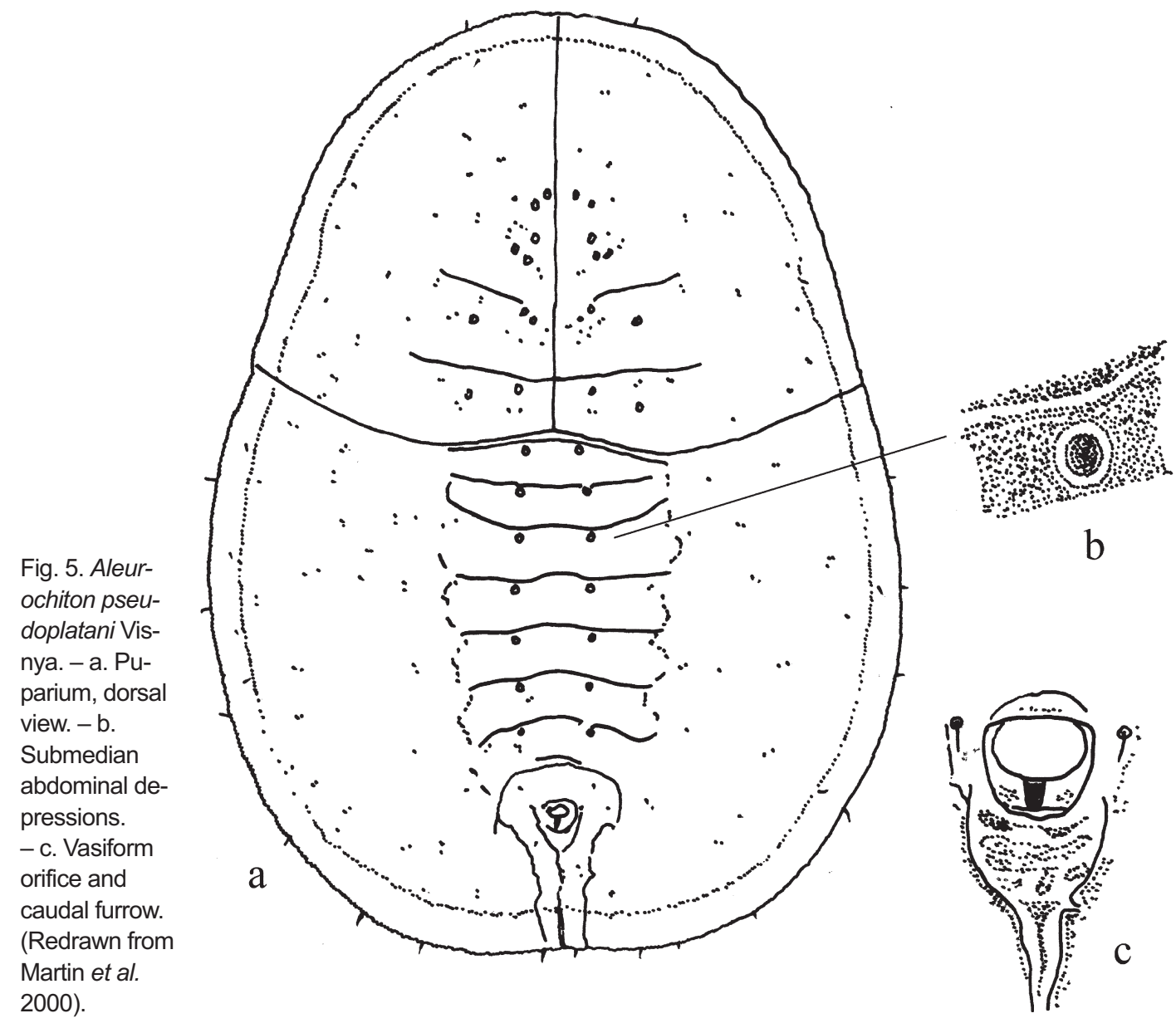

Distribution. China (Shaanxi); Russian Far East (Okeanskaya) (Danzig 1966).

Comments. Aleurochiton orientalis is closest to Aleurochiton aceris (Modeer), but the structure of the anal cleft is different and it has considerably more twin pores in compact groups, and also has one pair of conjugate setae on the dorsal mesothorax and also on metathorax. The phenomenon of conjugate setae (pairs of adjacent setal bases actually contiguous) is most unusual and Danzig appears to have used the term solely for $A$. orientalis. Danzig clearly stated that $A$. orientalis has just two generations annually, with summer and overwintering puparia, a characteristic shared only by other Aleurochiton species and by Pealius quercus. Therefore, it will be interesting to investigate the biologies of other cool-to-cold temperate whiteflies with that characteristic.

\section{Biological aspects of Aleurochiton orientalis}

Mainly because of the seasonal dimorphism, this new genus and species record is an interesting addition to the whitefly fauna of China and to the worldwide distribution of Aleurochiton. Based on the known distribution of $A$. orientalis, it should be regarded as a Palaearctic species, and it may be also distributed in northern China and northeastern China. How far westwards this species may occur may be governed by the distribution of the host, Acer mono.

The specimens of $A$. orientalis were found 12 per leaf, centrally on the under surface of leaves and only few specimens could be found. There was no evident damage to the maple. No parasitoids were obtained from cultures. No ant attendance was observed. 


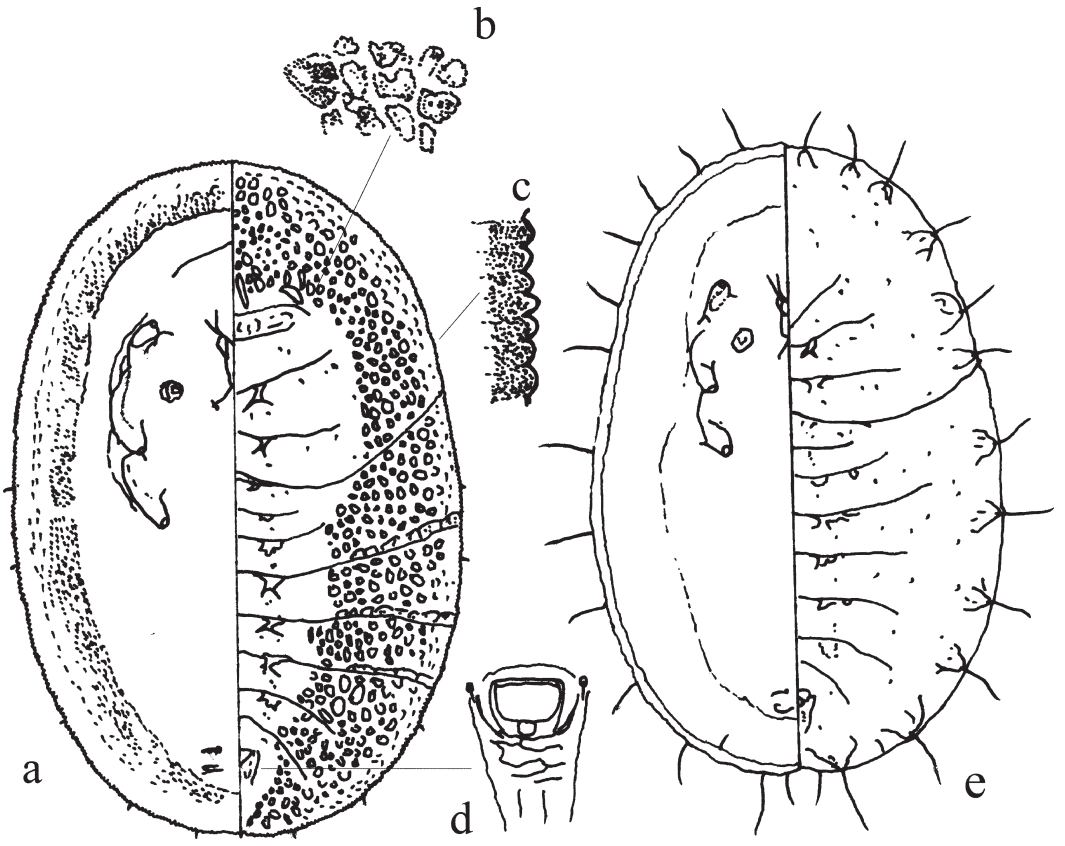

Fig. 6. Aleurochiton acerinus Haupt. - a. Overwintering puparium, ventral (left) and dorsal (right) view. - b. Pores and granules. - c. Margin. - d. Vasiform orifice and caudal furrow. - e. Summer puparium, ventral (left) and dorsal (right) view. (Redrawn from Martin et al. 2000).
As Danzig (1966), we also observed a particular feature of $A$. orientalis, namely that the larval exuviae of the three earlier instars are present on the dorsum of the puparium firmly attached to each other. This has not been found in other spe- cies of Aleurochiton. All of the described species of Aleurochiton are only known from maples (Acer) (Haupt 1934, Müller 1962, Danzig 1966, Martin et al. 2000, Evans 2008), including our specimens of $A$. orientalis, from Acer mono. With
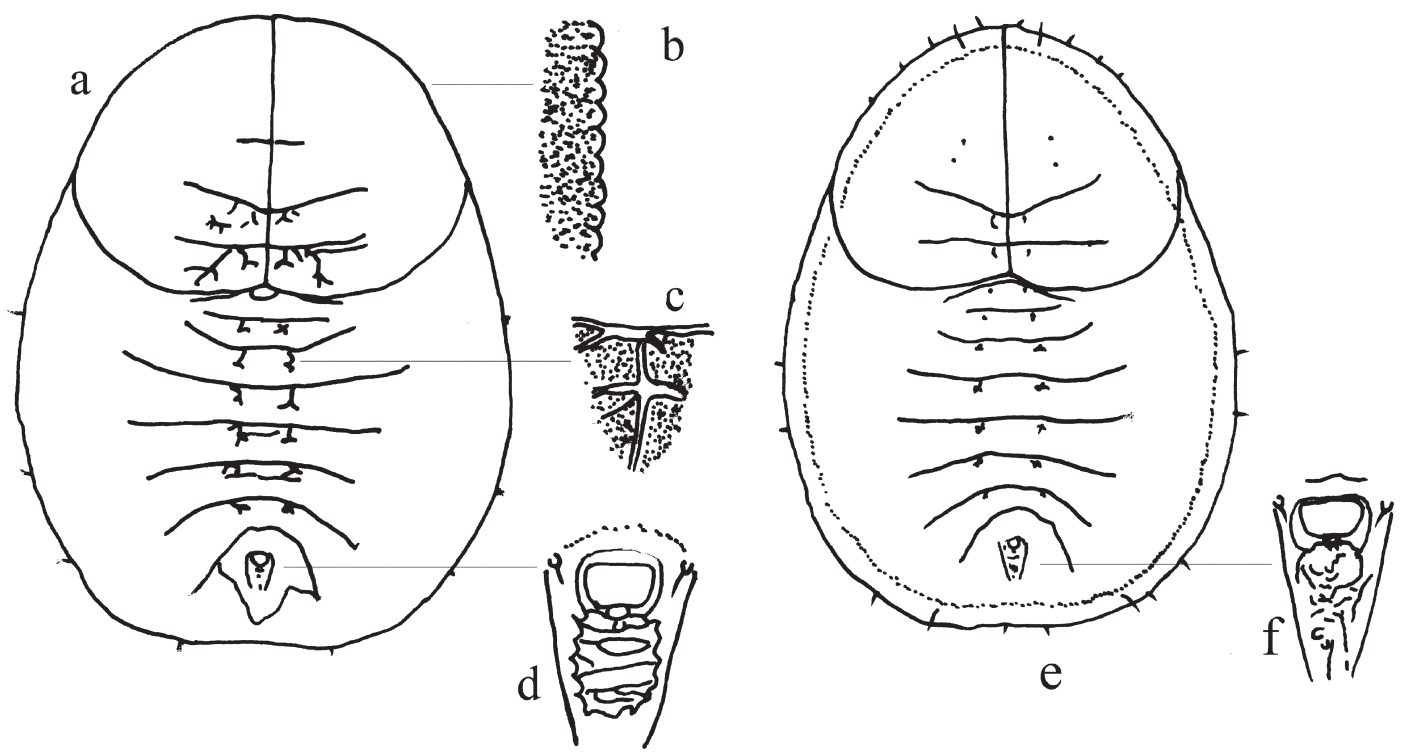

Fig. 7. Aleurochiton aceris (Modeer). - a. Overwintering puparium, dorsal view. - b. Margin. - c. Submedian abdominal depressions. - d. Vasiform orifice. - e. Summer puparium, dorsal view. - f. Vasiform orifice. (Redrawn from Martin et al. 2000). 


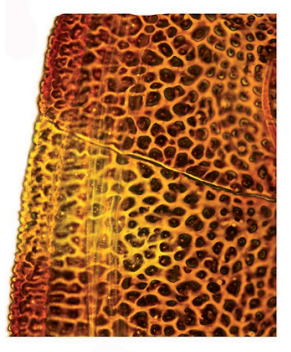

c

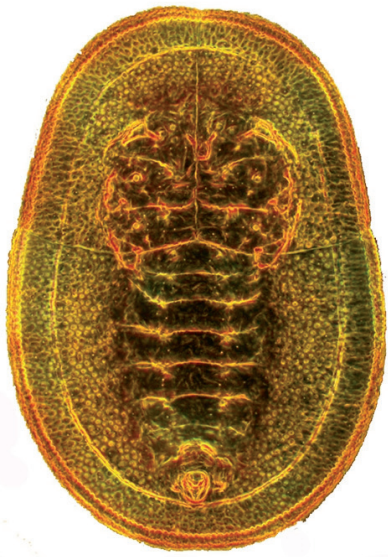

a

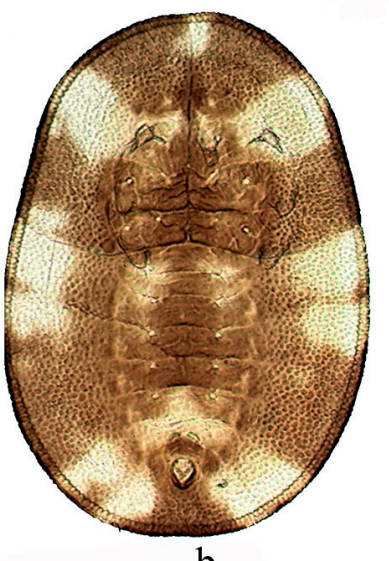

b

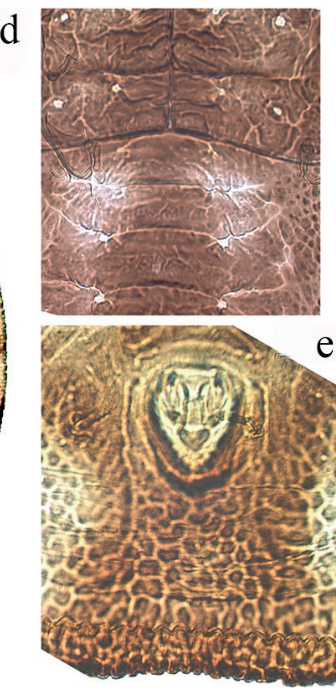

Fig. 8. Aleurochiton forbesii (Ashmead), USA, Pennsylvania, Millersville, on Acer saccharium, 19.IX.1973, Col. W. Blosser. - a. Puparium, dorsal view. - b. Slide-mounted specimen, puparium, dorsal view. - c. Margin and submarginal area. - d. Submedian abdominal depressions. - e. Vasiform orifice. (USDA - United States Department of Agriculture) (from John W. Dooley and Gregory A. Evans)

the higher taxonomy of many whitefly groups being poorly known Aleurochiton stands out as one of only a few whitefly genera that appear only to colonise hosts of a single plant genus.

\section{Key to puparia of Aleurochiton species}

The tendency for species of Aleurochiton to have two more-or-less dissimilar puparial forms makes the construction of a puparial key very difficult, despite there only being five species. The key below was constructed with the aid of actual specimens of all of the Aleurochiton species and we hope it will aid identification despite the difficulties.

1. With 1 or 2 pairs of conjugate setae (Figs. 2a, 3a, 4b) on dorsum. On Acer mono, far eastern Palaearctic orientalis Danzig

- Without conjugate setae on dorsum 2

2. Submedian abdominal depressions small but well-defined, subcircular (Fig. 5b). On Acer pseudoplatanus, Europe, western Russia pseudoplatani Visnya

- Submedian abdominal depressions poorly defined (Fig. 6a, e, 7c, e, 8d)
3. Vasiform orifice (Fig. 8e) relatively large, cordate, a little longer than wide, situated on a shallow elevation, lingula well developed and with a pair of terminal setae. Overwintering puparia often with a characteristic brown pigmented pattern (Fig. 8a, b). On several Acer species, Nearctic Region (North America) forbesii (Ashmead)

- Vasiform orifice smaller, trapezoidal, not elevated, operculum occupying most of the orifice. Not found in Nearctic Region

4. Outer submargin of summer puparia with 12 pairs of long, stout submarginal setae, much longer than the caudal setae (Fig. 6e); overwintering puparia with minute submarginal setae, much shorter than $8^{\text {th }}$ abdominal setae (Fig. 6a); overwintering puparia with submedian zone of venter delineated by an irregular fold, best defined cephalically and close to posterior abdominal spiracles (Fig. 6a). On Acer campestre, Europe

acerinus Haupt

- Spring/summer puparia with short, minute setae in outer submargin (Fig. 7a, 7e). Overwintering puparia with submedian zone of venter not well defined. On Acer platanoides, Europe 
Acknowledgements. We are thankful to the Natural History Museum, London (BMNH) (as copyright holder) for providing the right of using the pictures of $A$. acerinus, $A$. aceris and $A$. pseudoplatani, previously used in Martin et al. (2000). We express our deep gratitude to John W. Dooley and Gregory A. Evans (USDA/Animal Plant Health Inspection Service (APHIS)) for providing the images of $A$. forbesii. The helpful suggestions for the improvement of the text by an anonymous reviewer are also appreciated. We express our deep gratitude to the Testing Center of Yangzhou University for using the Philips XL30Environmental Scanning Electron Microscope. This research was funded by China Postdoctoral Science Foundation (2016M592017), the National Natural Science Foundation of China (31601884), the Special Fund for Agroscientific Research in the Public Interest of China (201303019).

\section{References}

Ashmead, W. H. 1893: Monograph of the North American Procotrypidae. Amitus Haldemann. - Bulletin of the United States National Museum 45: 292-294.

Bink-Moenen, R. M. 1983: Revision of the African whiteflies (Aleyrodidae). - Monografieën van de Nederlandse Entomologische Vereniging. Amsterdam 10: 1-211.

Danzig, E. M. 1966: The whiteflies (Homoptera, Aleyrodoidea) of the southern Primor'ye (Soviet Far East). —Entomologicheskoe Obozrenie 45: 364-386. [English translation in Entomological Review. Washington 45: 197-209 (1974).]

Evans, G. A. 2008: The whiteflies (Hemiptera: Aleyrodidae) of the world and their host plants and natural enemies. Version 070606. [www document]. URL http://keys.lucidcentral.org/keys/v3/whitefly/PDF PwP\%20ETC/world-whitefly-catalog-Evans.pdf. (Site visited on 21 March, 2016).

Gill, R. J. 1990: The morphology of whiteflies. — In: Gerling, D. (ed.), Whiteflies: Their Bionomics, Pest Status and Management: 13-46. Intercept. Andover. 347 pp.

Haupt, H. 1934: Neues er die Homoptera Aleurodina. Deutsche Entomologische Zeitschrift: 127-141.

Martin, J. H. 1985: The whitefly of New Guinea (Homoptera: Aleyrodidae). — Bulletin of the British Museum (Natural History) (Entomology) 50: 303-351.
Martin, J. H. 1987: An identification guide to common whitefly pest species of the world (Homoptera, Aleyrodidae). - Tropical Pest Management 33: 298-322.

Martin, J. H., Mifsud, D. \& Rapisarda, C. 2000: The whiteflies (Hemiptera: Aleyrodidae) of Europe and the Mediterranean Basin. - Bulletin of Entomological Research 90: 407-448.

Martin, J. H. \& Mound, L. A. 2007: An annotated checklist of world whiteflies (Insecta: Hemiptera: Aleyrodidae). - Zootaxa 1492: 1-84.

Mound, L. A. \& Halsey, S. H. 1978: Whitefly of the World. A systematic catalogue of the Aleyrodidae (Homoptera) with host plant and natural enemy data. - British Museum (Natural History), Chichester, 340 pp.

Modeer, A. 1778: Om fastflyet Coccus. — Göteborgs Kungl. Vetenskaps och Vitterhets Samhälles Handlingar. - Ny Tidsföljd 1: 11-50.

Müller, H. J. 1962: Zur biologie und morphologie der saisonformen von Aleurochiton complanatus (Baerensprung 1849) (Homoptera: Aleyrodidae). - Zeitschrift Für Morphologie Und Ökologie Der Tiere 51(3): 345-374.

Sampson, W. W. 1943: A generic synopsis of the Hemipterous Superfamily Aleyrodoidea. - Entomologica Americana 23: 173-223.

Signoret, V. 1868: Essai monographique sur les aleurodes. - Annales de la Soci Entomologique de France 8: 369-402.

Takahashi, R. 1954: Key to the tribes and genera of Aleyrodidae of Japan, with descriptions of three new genera and one new species (Homoptera). — Insecta Matsumurana 18: 47-53.

Tullgren, A. 1907: Über einige Arten der Familie Aleurodidae. - Arkiv für Zoologi 3: 1-18.

Visnya, A. 1936: További molytetvek köszegröl és vidékeröl. Weitere Mottenläuse aus der Umgebung von Köszeg. - Folia sebariensis vasi Szle 3: 116-117.

Wang, J. R., Dubey, A. K. \& Du, Y. Z. 2014: Description of a new species of Aleuroclava Singh (Hemiptera: Aleyrodidae) from China. — Florida Entomologist 97(2): 685-91.

Zahradnik, J. 1963: Aleyrodina. — Die Tierwelt Mitteleuropas (N.S.) 4: 1-9.

Zahradnik, J. 1987: La révision des aleurodes des pays Tchêques (Sternorrhyncha: Aleyrodinea). II. — Vestník Československé Společnosti Zoologické 51: 6080. 